\title{
CULTURE CONDITIONS FOR THE PRODUCTION OF THERMOSTABLE AMYLASE BY BACILLUS SP
}

\author{
Carlos Eduardo de Souza Teodoro; Meire Lelis Leal Martins*
}

Universidade Estadual do Norte Fluminense, Centro de Ciências e Tecnologias Agropecuárias, Campos, RJ, Brasil

Submitted: May 15, 2000; Returned to authors for corrections: July 18, 2000; Approved: November 14, 2000

\begin{abstract}
Studies on the $\alpha$-amylase production were carried out with a bacterial strain isolated from a soil sample. The cells were cultivated in a mineral medium containing soluble starch as sole carbon source. The addition of calcium $(10 \mathrm{mM})$ or peptone $(1 \%)$ and yeast extract $(0.5 \%)$ to the mineral medium shortened the lag period and improved the growth and $\alpha$-amylase synthesis. The addition of glucose to the culture diminished greatly the synthesis of $\alpha$-amylase, demonstrating that a classical glucose effect is operative in this organism. The optimum temperature and initial medium $\mathrm{pH}$ for amylase synthesis by the organism were $50^{\circ} \mathrm{C}$ and 7.0 respectively. The optimal $\mathrm{pH}$ and temperature for activity were 6.0 and $50^{\circ} \mathrm{C}$ respectively. The enzyme extract retained $100 \%$ activity when incubated for one hour at $90^{\circ} \mathrm{C}$ and $40 \%$ at $60^{\circ} \mathrm{C}$ for $24 \mathrm{~h}$. The addition of glucose to the culture diminished greatly the synthesis of $\alpha$-amylase.
\end{abstract}

Key words: $\alpha$-amylase, thermophilic bacterium, thermostable enzymes, Bacillus sp

\section{INTRODUCTION}

Recent discoveries of starch degrading enzymes have led to increased application of amylases in various industrial processes (1). The c-amylase (1,4- $\alpha$-D-glucan glucanohydrolase, EC 3.2.1.1) hydrolyses $\alpha 1,4$ glucosidic linkages in starch and related substrates $(5,18,23)$. This enzyme has extensive commercial applications in starch liquefaction, brewing, sizing in textile industries, and paper and detergent manufacturing processes $(4,13,20,21)$. Thermostability is a feature of most of the enzymes sold for bulk industrial usage and thermophilic organisms are therefore of special interest as a source of novel thermostable enzymes. Recent research with thermostable $\alpha$-amylases has concentrated on the enzymes of thermophiles and extreme thermophiles $(2,3,7,8,16,17,20)$ and little is known about the properties of the enzymes produced by these organisms. The present study deals with the isolation and identification of a bacterium and describes the effects of culture conditions on the activity of $\alpha$-amylase.

\section{MATERIALS AND METHODS}

Culture medium. Agar plate A consisted of $2 \%$ Bactotryptone, $1 \%$ Bacto-yeast extract, $1 \% \mathrm{NaCl}$ and $2 \%$ agar at $\mathrm{pH}$ 7.0. This was used for selection of thermophilic bacteria.

Agar plate B contained $1 \%$ soluble starch, $0.2 \%$ yeast extract, $0.5 \%$ peptone, $0.05 \% \mathrm{MgSO}_{4}, 0.05 \% \mathrm{NaCl}, 0.015 \%$ $\mathrm{CaCl}_{2}$ and $2 \%$ agar at $\mathrm{pH}$ 7.0. This was used for screening bacteria capable of producing starch digesting enzymes.

The liquid medium contained $(\mathrm{g} / \mathrm{L})$ : Soluble starch 10.0, $\mathrm{NaH}_{2} \mathrm{PO}_{4} \cdot 2 \mathrm{H}_{2} \mathrm{O} 1.56, \mathrm{NH}_{4} \mathrm{Cl} 5.35, \mathrm{KCl} 0.745, \mathrm{Na}_{2} \mathrm{SO}_{4} \cdot 10 \mathrm{H}_{2} \mathrm{O}$ 0.644 , Citric acid $0.42, \mathrm{MgCl}_{2} \cdot 6 \mathrm{H}_{2} \mathrm{O} 0.25, \mathrm{CaCl}_{2} 2.2 \times 10^{-3}, \mathrm{ZnO}$ $2.5 \times 10^{-3}, \mathrm{FeCl}_{3} .6 \mathrm{H}_{2} \mathrm{O} 2.7 \times 10^{-2}, \mathrm{MnCl}_{2} \cdot 4 \mathrm{H}_{2} \mathrm{O} 1.0 \times 10^{-2}$, $\mathrm{CuCl}_{2} .2 \mathrm{H}_{2} \mathrm{O} 8.5 \times 10^{-4}, \mathrm{CoCl}_{2} \cdot 6 \mathrm{H}_{2} \mathrm{O} 2.4 \times 10^{-3}, \mathrm{NiCl}_{3} \cdot 6 \mathrm{H}_{2} \mathrm{O}$ $2.5 \times 10^{-4}, \mathrm{H}_{3} \mathrm{BO}_{4} 3.0 \times 10^{-4}, \mathrm{Na}_{2} \mathrm{MoO}_{4} 1.0 \times 10^{-3}$ and Biotin $1.0 \times 10^{-3}$. The $\mathrm{pH}$ was adjusted to 7.0 and the medium sterilised by autoclaving at $121^{\circ} \mathrm{C}$ and 15 psi for $30 \mathrm{~min}$.

Isolation and determination of thermophilic bacterium producing $\boldsymbol{\alpha}$-amylase. Soil suspensions in sterilised water were poured and spread onto agar plates A. These plates were

\footnotetext{
* Corresponding author. Mailing address: Universidade Estadual do Norte Fluminense, Centro de Ciências e Tecnologias Agropecuárias, Av. Alberto Lamego, 2000, CEP 28015-620, Campos, RJ, Brasil. Telefax: (+5524) 726-3746.
} 
incubated at $55^{\circ} \mathrm{C}$ for 2 days. The colonies that were found on the plates were transferred onto agar plates $\mathrm{B}$. These plates were incubated at $55^{\circ} \mathrm{C}$ for 2 days. Several amylase-producing bacterial colonies were selected after flooding the plates with iodine solution. The strain that yielded a high level of $\alpha$-amylase was selected for further experiments.

Cultural conditions. The organism was germinated on agar plate B, as described by Liao et al. (19), and the plates were incubated at $55^{\circ} \mathrm{C}$ for 18 hours. Liquid medium (approximately $5 \mathrm{ml}$ ) was pipetted into the agar plates B and the cells scraped off using a sterile Pasteur pipette. Liquid medium $(50 \mathrm{ml}$ contained in a $250 \mathrm{ml}$ Erlenmeyer flask) was inoculated with this suspension to give an initial absorbance at $470 \mathrm{~nm}$ of at least 0.1 and the cultures were incubated at $50^{\circ} \mathrm{C}$ with vigorous aeration in a shaker at $250 \mathrm{rpm}$ for 96 hours. Before assay, the cells were separated by centrifugation at $5000 \mathrm{~g}$. The clear supernatant was used as crude enzyme preparation.

Experiments to determine the effect of temperature and $\mathrm{pH}$ on the growth of the organism and $\alpha$-amylase production were carried out at temperatures varying from $30^{\circ} \mathrm{C}$ to $60^{\circ} \mathrm{C}$, and at various values of $\mathrm{pH}$ varying from 4.0 to 9.0 for 40 hours.

Bacterial dry weight. Dry weight of the cells was determined using the method of Herbert et al. (12). Duplicate samples $(5 \mathrm{ml})$ were centrifuged at $3000 \mathrm{~g}$ for $10 \mathrm{~min}$ and washed once in distilled water. The cells were resuspended in distilled water $(2 \mathrm{ml})$ and poured into pre-weighted foil thimbles. Additional aliquots of water $(2 \times 2 \mathrm{ml})$ ensured that all remaining cells were washed out into the thimbles. These were then, dried to constant weight in an oven at $105^{\circ} \mathrm{C}$. The thimbles were cooled in a desiccator and weighted on an analytical balance sensitive to $0.1 \mathrm{mg}$.

Analytical procedure. The amylase assay was based on the reduction in blue colour intensity resulting from enzyme hydrolysis of starch (4). The reaction contained $1 \mathrm{ml}$ enzyme (cell free supernatant) and $10 \mathrm{ml}$ of $1 \%$ starch solution incubated at $50^{\circ} \mathrm{C}$ for $10 \mathrm{~min}$. The reaction was stopped by adding $10 \mathrm{ml}$ of $0.1 \mathrm{~N} \mathrm{HCl}$. One millilitre of this acidified solution was added to $10 \mathrm{ml}$ of $0.1 \mathrm{~N} \mathrm{HCl}$. From this, $1 \mathrm{ml}$ was added to $10 \mathrm{ml}$ iodine solution $(0.05 \%$ iodine in $0.5 \% \mathrm{KI})$. The optical density of the blue-coloured solution was determined at $660 \mathrm{~nm}$. The same procedure was repeated using $1 \mathrm{ml}$-distilled water instead of the enzyme sample in order to measure the optical density without the enzyme. One unit of enzyme activity (DUN) is defined as the quantity of enzyme that causes $1 \%$ reduction of blue colour intensity of starch-iodine solution a $50^{\circ} \mathrm{C}$ in $1 \mathrm{~min}$.

Effect of temperature on enzyme activity. The enzyme's activity profile was obtained by measuring enzymatic activities in $0.1 \mathrm{M}$ citric acid-sodium phosphate buffer, $\mathrm{pH}$ 6.0, between $30^{\circ} \mathrm{C}$ and $90^{\circ} \mathrm{C}$.

Effect of pH on enzyme activity. The effect of $\mathrm{pH}$ on $\alpha$ amylase activity was investigated by measuring enzyme activity at $50^{\circ} \mathrm{C}$ in different buffer solutions.

\section{RESULTS AND DISCUSSION}

Isolation and determination of thermophilic bacterium producing $\boldsymbol{\alpha}$-amylase. The strain was a Grampositive bacillus, negative on the Voges-Proskauer test (at $\mathrm{pH}$ 7.2), and facultative anaerobic. It was actively motile, 2.5 to $3.0 \mu \mathrm{m}$ long and approximately $0.6 \mu \mathrm{m}$ wide, with central spores and predominantly unswollen cylindrical sporangia. The strain possessed the ability to hydrolyse both starch and gelatin. Catalase was positive. Indole was not formed, and acetoin formation was positive. Nitrates were reduced to nitrites. The final $\mathrm{pH}$ after growth in glucose-broth was about 5.5 and growth was obtained in nutrient broth containing 7\% $\mathrm{NaCl}$. The strain grew in nutrient broth at $30^{\circ} \mathrm{C}$ to $60^{\circ} \mathrm{C}$ with an optimum at $50^{\circ} \mathrm{C}$ for $24 \mathrm{~h}$. From these results, the strain was identified as Bacillus sp by the criteria of Bergey's Manual of Systematic Bacteriology.

Enzymatic production. Measurements of the enzyme activity and cell growth of Bacillus sp at a number of time intervals are shown in Fig. 1. Initially, the organism was grown in the liquid medium (Fig.1a) and then, in the liquid medium supplemented with calcium $(10 \mathrm{mM})$ (Fig. 1b). The addition of $10 \mathrm{mM}$ calcium to the liquid medium improved the growth and amylase production. Since the enzyme is known to be a calcium metalloenzyme, it is possible that the results found were because of the more availability of calcium ion. These results are similar to the findings of Hewitt and Solomons (13), with cultures of Bacillus amyloliquefaciens.

The amylase synthesis by several microorganisms has been correlated to the presence or absence of various amino acids and complex nitrogenous sources in the culture medium $(9$, $13,14)$. Indeed, the addition of yeast extract $(0.5 \%)$ and peptone $(1 \%)$ to the liquid medium shortened the lag period and increased both the dry weight of the cell and the enzyme synthesis (Fig. 2). Therefore, the result suggests that yeast extract and peptone is favoured for the growth and synthesis of amylase by the organism studied.

It has been reported that the synthesis of carbohydratedegrading enzymes in most species of the genus Bacillus is subject to catabolic repression by readily metabolizable substrates such as glucose (20). Ours results are in good agreement with these findings. The addition of glucose $(0.5 \%)$ to the culture diminished greatly the synthesis of $\alpha$-amylase (Fig. 3). These results are similar to the findings of Haseltine et al. (10), who observed that glucose represses the production of $\alpha$-amylase in the hyperthermophilic archaeon Sulfolobus solfataricus. According to them glucose prevented $\alpha$-amylase gene expression and not merely secretion of preformed enzyme.

The organism did not grow in the culture media adjusted to $\mathrm{pH} 4.0,5.0,6.0$ and 10.0 (Fig.4). In those media where bacterial growth occurred, $\mathrm{pH}$ increased after 18 hours of fermentation, never reaching values greater than 9.0. The 
(a)

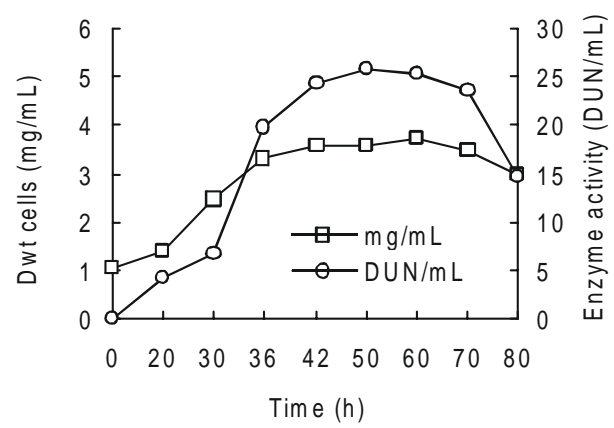

(b)

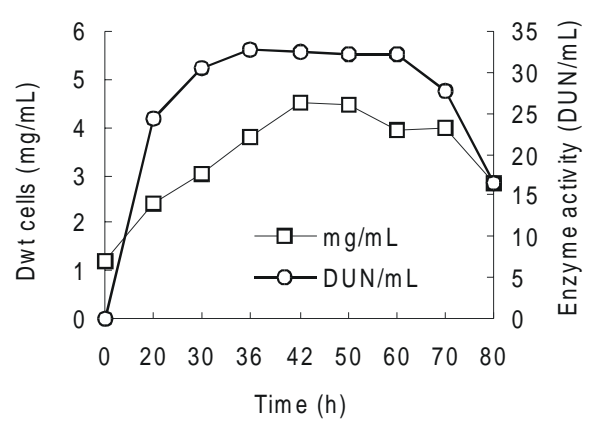

Figure 1. Time course of growth and $\alpha$-amylase production by Bacillus sp in liquid medium (a) and in liquid medium supplemented with calcium (b).

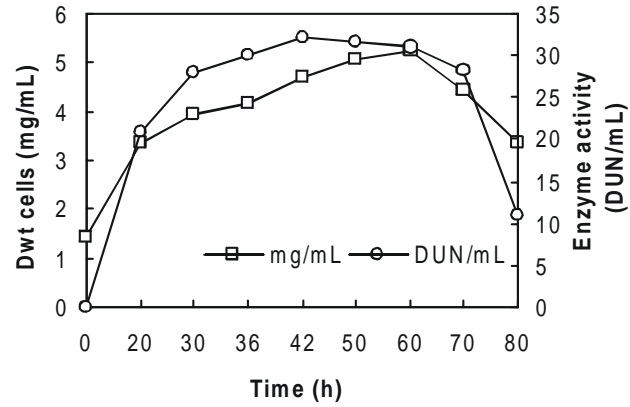

Figure 2. Time course of growth and $\alpha$-amylase production by Bacillus sp in liquid medium supplemented with yeast extract and peptone.

enzyme activity of the broth increased during 72 hours of incubation at all $\mathrm{pH}$ values.

These results suggest that there is a stimulation of enzyme synthesis at $\mathrm{pH} 7.0$ and that the higher enzyme production at this $\mathrm{pH}$ was a result of increased cell growth. The optimum $\mathrm{pH}$ for enzyme activity was between 6.0 and 6.5 . There was a nearly $73 \%$ reduction in maximum activity at $\mathrm{pH} 8.5$ or 9.0. Regarding to Bacillus genus they produced enzymes with optimum activities at $\mathrm{pH}$ values as low as 3.5 or as high as $10.6(15,11)$.

Growth and enzyme production both increased with temperature within the range of $30^{\circ} \mathrm{C}$ to $50^{\circ} \mathrm{C}$ with an optimum of $50^{\circ} \mathrm{C}$ (Fig. 5a). Thus, the results indicated that the optimum temperatures for amylase synthesis and growth were the same.

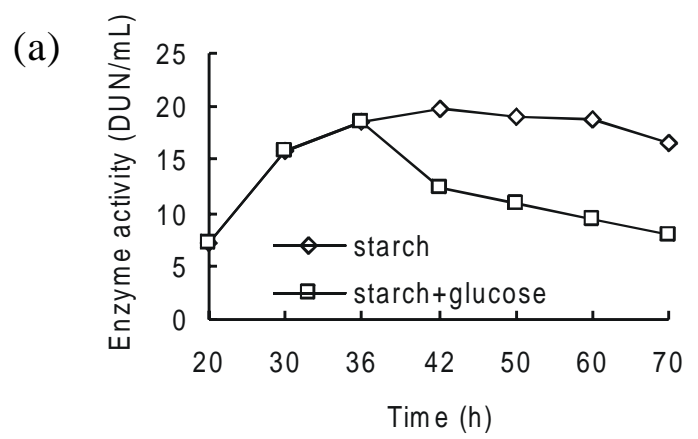

Other investigators also reported that maximum amylase production occurred at the optimum growth temperature $(4,20,22)$.

The optimum temperature for enzyme activity was between $45^{\circ} \mathrm{C}$ and $55^{\circ} \mathrm{C}$. A reduction in enzyme activity was observed at values above $60^{\circ} \mathrm{C}$ (Fig. 5b).

According to the results presented the optimal conditions for the cell growth were adequate for enzyme production. These results contrast with the findings found by Chandra et al. (6) to Bacillus licheniformis CUM 305. This organism did not produce $\alpha$-amylase at $30^{\circ} \mathrm{C}$ although it grew very well at this temperature. In addition, Saito and Yamamoto (22), studied a Bacillus licheniformis which produced a-amylase at temperatures around $50^{\circ} \mathrm{C}$ and never produced the enzyme at temperatures lower than $45^{\circ} \mathrm{C}$.

The enzyme extract retained $100 \%$ activity when incubated for one hour at $90^{\circ} \mathrm{C}$ (Fig. 6a). After this time the activity decreased drastically. After 24 hours at $50^{\circ} \mathrm{C}$ and $60^{\circ} \mathrm{C}$, the enzyme retained $65 \%$ and $62 \%$ of its initial activity (Fig. 6b) and was inactivated on incubation at $95^{\circ} \mathrm{C}$ for $10 \mathrm{~min}$.

A temperature stable $\alpha$-amylase from Bacillus licheniformis 584 was reported by Saito and Yamamoto (22). This enzyme rapidly lost activity at temperatures above $76^{\circ} \mathrm{C}$. According to the results presented in this article, the $\alpha$-amylase from the Bacillus sp isolated, is heat stable, although it showed optimum activity lower than that described for the $\alpha$-amylase produced by Bacillus sp $(4,20)$.

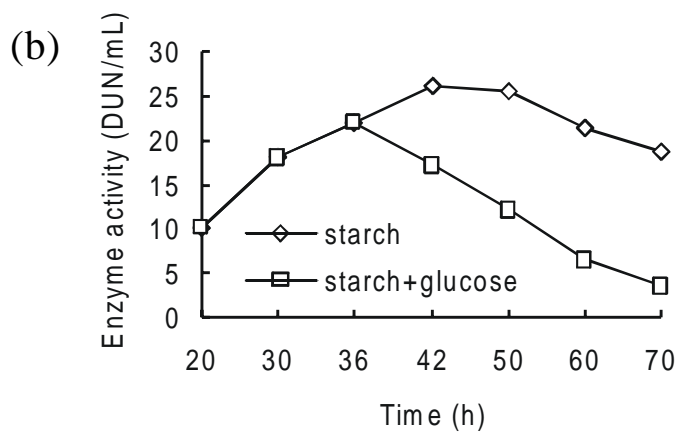

Figure 3. Glucose repression of $\alpha$-amylase production. Cells of Bacillus sp were growth in the liquid medium with $0.5 \%$ (a) and $1.0 \%$ (b) of starch. 
(a)

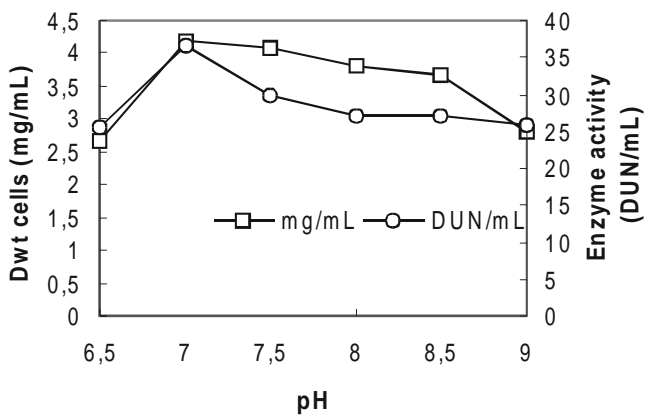

(b)

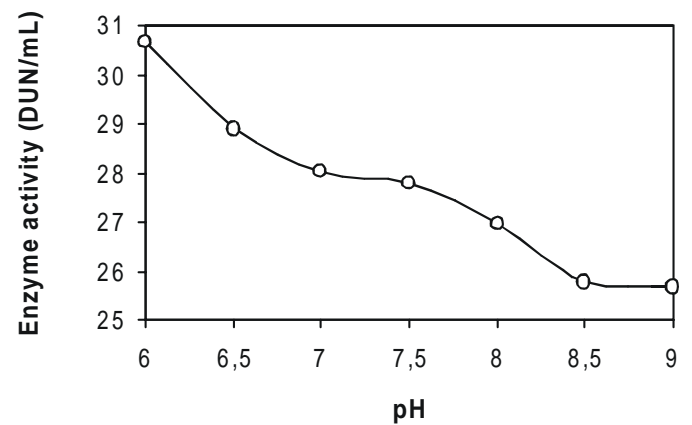

Figure 4. Effect of the initial $\mathrm{pH}$ of the culture medium on growth and $\alpha$-amylase production by Bacillus sp (a) and effect of the $\mathrm{pH}$ on the aamylase activity at $50^{\circ} \mathrm{C}(\mathrm{b})$.

(a)

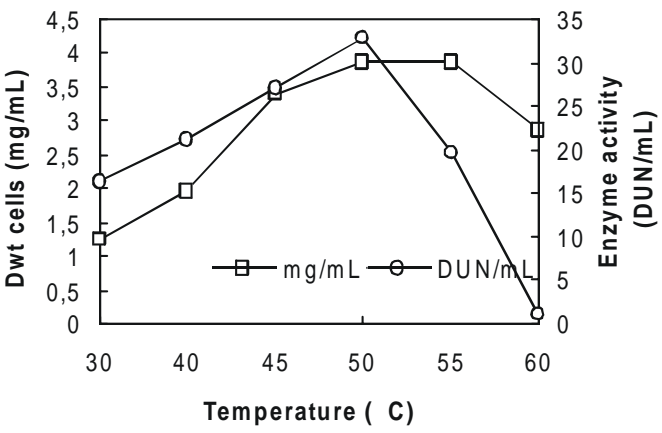

(b)

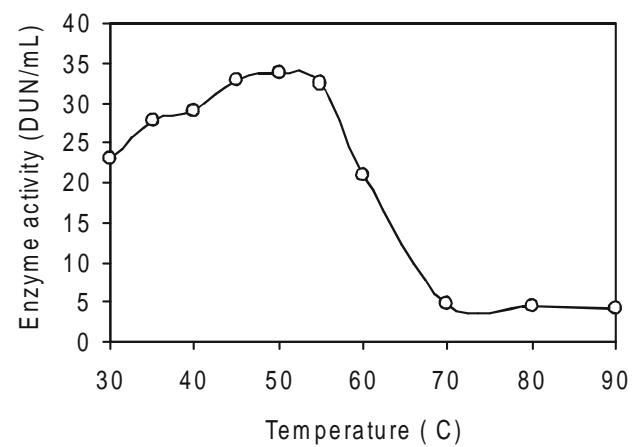

Figure 5. Effect of the temperature on the growth and $\alpha$-amylase activity of Bacillus sp (a) and effect of temperature on $\alpha$-amylase activity (b).

(a)

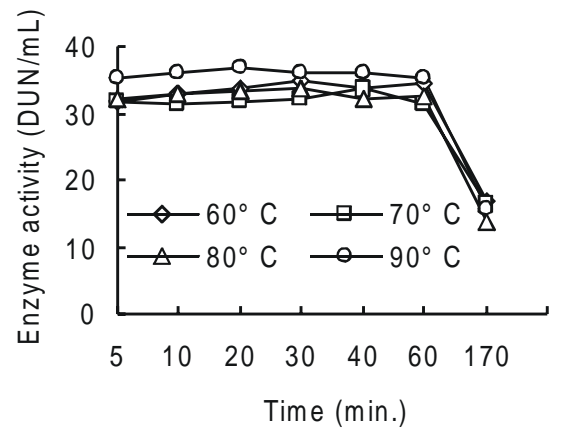

(b)

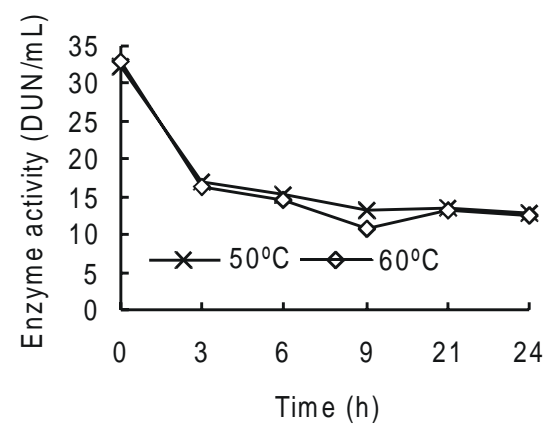

Figure 6. Effect of temperature on the stability of $\alpha$-amylase. 


\section{ACKNOWLEDGMENTS}

We are grateful to Mr Silvia M. Faria for the help in identifying the organism. This work was supported by the research grant from FAPERJ (Fundação de Amparo a Pesquisa do Rio de Janeiro).

\section{RESUMO}

\section{Condições de cultura para produção de amilase termoestável por Bacillus sp}

Estudos sobre a produção de $\alpha$-amilase foram realizados com uma bactéria isolada a partir de amostras de solo. As células foram cultivadas em um meio mineral contendo amido como única fonte de carbono. A adição de cálcio $(10 \mathrm{mM})$ ou peptona $(1,0 \%)$ e extrato de levedura $(0,5 \%)$ ao meio mineral, encurtou o período lag, melhorou o crescimento e a síntese de $\alpha$-amilase. A adição de glicose a cultura diminuiu grandemente a síntese de $\alpha$-amilase, demonstrando que o efeito glicose ocorre neste microrganismo. A temperatura ótima e o pH inicial ótimo para a síntese da amilase pelo organismo foram $50^{\circ} \mathrm{C}$ e 7,0 respectivamente. $\mathrm{O} \mathrm{pH}$ e temperatura ótima para atividade foram 6,0 e $50^{\circ} \mathrm{C}$ respectivamente. $\mathrm{O}$ extrato enzimático reteve $100 \%$ de atividade quando incubado por uma hora a $90^{\circ} \mathrm{C}$ e $40 \%$ a $60^{\circ} \mathrm{C}$ por 24 horas. A adição de glicose ao meio de cultura diminuiu grandemente a síntese de $\alpha$-amilase.

Palavras-chave: $\alpha$-amilase, bactéria termofílica, enzimas termoestáveis, Bacillus sp.

\section{REFERENCES}

1. Aboud-zeid, A.M. Production and characterization of an extracellular $\alpha$ amylase enzyme from Aspergillus flavus. Microbios. 89: 55-66, 1997.

2. Adams, P.R. Growth and amylase production in Sporotrichum thermophile Apinis. Biotech. Appl. Biochem. 26:169-170, 1997.

3. Arnesen, S.; Eriksen, S.H.; Olsen, J. and Jensen, B. Incresed production of $\alpha$-amylase from Thermomyces lanuginosus by the addition of tween 80 . Enz. Microbial Tech. 23: 249-252, 1998.

4. Bajpai, P. and Bajpai, P. High-temperature alkaline $\alpha$-amylase from Bacillus licheniformis TCRDC-B13. Biotech. Bioeng. 33: 72-78, 1989.
5. Bolton, D.J.; Kelly, C.T. and Fogarty, W.M. Purification and characterization of the $\alpha$-amylase of Bacillus flavothermus. Enz. Microbial Technol. 20: 340-343, 1997.

6. Chandra, A. K.; Medda, S. and Bhadra, A.K. Production of extracellular thermostable $\alpha$-amylase by Bacillus licheniformis. J. Ferment. Technol. 58: $1-10,1980$.

7. Dobreva, E.; Tonkova,A.; Ivanova, V.; Stefanova,M.; Kabaivanova, L. and Spasova, D. Immobilization of Bacillus licheniformis cells, producers of thermostable $\alpha$-amylase, on polymer membranes. J. Ind. Microbiol. Biotech. 20: 166-170, 1998.

8. Egas, M.C.V.; Costa, M.S.da; Cowan, D.A. and Pires, E.M.V. Extrecellular $\alpha$-amylase from Thermus filiformis Ork A2: purification and biochemical characterization. Extremophiles 2: 23-32, 1998.

9. Forgaty, W. M. and Kelly C.T. Microbial enzymes and Bioconversions: Amylases. Academic Press, New York, 1980, pp.115-170.

10. Haseltine, C.; Rolfsmeier, M. and Blum, P. The glucose effect and regulation of $\alpha$-amylase synthesis in the hyperthermophilic archaeon Sulfolobus solfataricus. J.Bacteriol. 178:945-950, 1996.

11. Hayashi, T.; Abiba, T. and Horikosh, K. Properties of a new alkaline maltohexose forming amylases. Appl. Microbiol. Biotechnol., 28:281285, 1988.

12. Herbert, D. The chemical composition of microorganisms as a function of their environment. Symp. Soc. Gen. Microbiol. 11:391416,1961.

13. Hewitt, C.J. and Solomons, G.L. The production of $\alpha$-amylase (E.C.3.2.1.1.) by Bacillus amyloliquefaciens, in a complex and a totally defined synthetic culture medium. J. Ind. Microbiol. 17: 96-99, 1996.

14. Hillier, P.; Wase, D.A.J. and Emery, A.N. Production of $\alpha$-amylase (E.C.3.2.1.1.) by Bacillus amyloliquefaciens in batch and continuous culture using a defined synthetic medium. Biotechnol. Lett. 18:795-800,1996.

15. Horikoshi, K. Production of alkaline enzymes by alkalophilic microorganisms. Agric. Biol. Chem.234:556-561, 1971.

16. Jana, M. and Pati, B. Thermostable, salt-tolerant $\alpha$-amylase from Bacillus sp. MD 124. J. Basic Microbiol. 37: 323-326, 1997.

17. Janda, L.; Pavelka, T.; Tichý, P.; Spízek, J. and Petricek, M. Production and properties of $\alpha$-glucosidase from the thermotolerant bacterium Thermonospora curvata. J. Appl. Microbiol. 83: 470-476, 1997.

18. Kelly, C.T.; Bolton, D.J. and Forgaty, W.M. Bi-phasic production of $\alpha$-amylase of Bacillus flavothermus in batch fermentation. Biotechnol. Lett. 19: 675$677,1997$.

19. Liao, H.; McKenzie, T. and Hageman, R. Isolation of a thermostable enzyme variant by cloning and selection in a thermophile. Proc. Nat. Acad. Sci. of the United States of America 83: 576-580, 1986.

20. Lin, L.L.; Chyau, C.C. and Hsu, W.H. Production and properties of a rawstarch-degrading amylase from thermofilic and alkaliphilic Bacillus sp. TS23. Biotech. Appl. Biochem. 28: 61-68, 1998.

21. Roychoudhury, S.; Parulekar, S.J. and Weigand, W.A. Cell growth and $\alpha$-amylase production characteristics of Bacillus amyloliquefaciens. Biotech. Bioen. 33: 197-206, 1989.

22. Saito, N. and Yamamoto, K. Regulatory factors affecting $\alpha$-amylase production in Bacillus licheniformis. J. Bacteriol. 121: 848-856, 1975.

23. Sidhu, G.S.; Sharma, P.; Chakrabarti, T. and Gupta, J.K. Strain improvement for the production of a thermostable $\alpha$-amylase. Enz. Microbial Technol. 21: 525-530, 1997. 